\title{
岡山における社寺林の研究（I）
}

一一市街地およびその近郊における全体構造一

\author{
坂本圭児 $*$ 石原晋二 ${ }^{* *} \cdot$ 千葉喬三 $*$
}

\section{Study on the Woods in Shrine or Temple Precincts of Okayama, Japan (I)}

- Total structure of the woods in shrine or temple precincts, in urban and suburban areas-

SaKamoto Keiji*, Ishinara Shinji** and Chiba Kyozo*

要旨

坂本圭児・石原晋二・千葉喬三 : 岡山における社寺林の研究 ( I ) 一市街地およびその近 郊における全体構造一

岡山市の市街地とその近郊の社寺林を対象にその維持機構を明らかにすることを目 的とし, 今回植生調查の結果をまとめて報告する。全体の種組成では, クスノキ (Cinnamomum camphora), イチョウ(Ginkgo biloba), ムクノキ (Aphananthe aspera), クロガネモチ (Ilex rotunda), エノキ(Celtis sinensis), ヒノキ(Chamaecyparis obtusa), アラカシ (Quercus glauca), スギ (Cryptomeria japonica), クロマッ (Pinus thunbergii)，イブキ (Juniperus chinensis) が優占度が高く, 主要 な樹種である。社寺林に多いとされる極相樹種，特にシイ，カシ類が少ないことが特徴で あった。主要な樹種の直径階分布からは，小径木の頻度が高く大径木まで連続的な分布を 示すムクノキ，エノキ，これと同様で特に大径木の頻度の割合が高いクスノキ，大径木の 頻度が高く小径木の頻度の低いイチョウ，小径木の頻度は高いが直径の幅が狭いクロガネ モチ, アラカシ，針葉樹という4つのタイプがあった。全体として小径木の頻度が高い連 続的な分布を示していた。多様性の問題に関しては, 面積との関係を検討した。種数一面 積関係では $\mathrm{S}=\mathrm{kA}^{\mathrm{z}}$ の関係が成り立ち, $\mathrm{z}$ の值が 0.585 で非常に高いのが特徴であった。 Shannon 関数と面積の間にも正の相関がみられ，面積が増加するにつれて多様性も增加 することが認められた。

1. はじめに

人間の生活環境の悪化にともない, 森林の環境保全機 能に対する期待が増大しつつある現段階においては; 新

* 岡山大学農学部

* Fac. of Agric., Okayama Univ.

** 名古屋市役所

** Nagoya City Office
たな樹林の造成と既存の樹林の保全が必要であり，その ための技術開発に積極的に取り組まなければならない。 千葉 $(1989)^{2)}$ は, 人間の生活環境の保全を直接的な目 的としその機能を保有する樹林を環境林と定義し，その 造成, 利用, 管理技術の開発のための研究の必要性と方 向性を提示した。環境林には, 造成による大規模緑地な どの樹林と既存の樹林を含めることができる。社寺林は, 既存の樹林として代表的なあのの 1 つであり，環境林と 
して研究対象とすることが不可欠である。

環境林として社寺林が果たす役割を考えると, 次の 2 点が重要である。まず, 社寺林の存在自体が環境林とし ての機能を保有していることがあげられる。社寺林は, 物理・化学的環境の快適性を確保するとともに，アメ二 ティを創出し、レクリエーションの場を提供する。文化 基盤としての役割も大きいと考えられる。あう1つの役 割としては社寺林の構造や環境林としての機能は, 環境 林の維持管理と新たな環境林造成のための基礎的な参考 となることである。社寺林は，宗教的な意味合を有する 独特な樹林であり量的，質的な変化があるとしてあ，長 期間にわたり樹林として維持されてきた樹林である。ど の様な管理形態，内部及び周辺環境のもとにどの様に維 持され，また，量的，質的に変化をしているのかを明ら かにすることは，今後の環境林造成と維持管理のために 貴重な情報を与えてくれる。

従来, 社寺林は土地開発の中で残されてきた貴重な植 生の遺存として関心がもたれ, 多くの成果が蓄積されて いる ${ }^{15)}$ 。このような生態学的な意義加ら原植生の推定が 可能とされ，また，環境保全地域の設定の基礎としての 役割，環境調節機能と精神的基盤などの社会的意義も強 調されている ${ }^{18)}$ 。しかし，個々の社寺林の生態学的調查 が主となり，しかも，保護区や比較的自然林に近い社寺 林に研究対象が絞られていたか，関心が生態学的な視点 に絞られていた傾向があった。環境林として社寺林を研 究対象とする場合には，幅広い社寺林を対象とし，生態 学的視点だけでなく，土地利用や管理形態との関係を具 体的に明確にすることが必要である。また，社寺林は孤 立林として存在することが多い。孤立した自然林の量的， 質的な変化とその維持管理の困難は，近年特に強調され るようになったが ${ }^{1,20)}$ ，社寺林においてこの点に注意し ておく必要がある。

本研究は, 以上の立場からあらためて社寺林に取り組 むため, 調査区域を岡山市に設定し，様々な土地利用の 地域にあり，管理形態も異なる社寺林においてその構造 を調査し社寺林の維持機構, 変遷を明らかにすることを 目的としている。今回市街地および近郊の平地部の社寺 林に絞り植生調查を行ったが，ここではまず，全体的な 構造とその特徴を報告することにしたい。

なお，本研究を進めるに当たり，現地調査において， 社寺関係者の方々からは調査の許可を頂き, 貴重な情報 を与えて頂いたことああった。また，岡山大学農学部森 林保全学研究室の大学院生, 学部学生諸氏にご協力頂い た。ここに深く感謝の意を表する次第である。

\section{2. 調查地，および調查方法}

岡山市市街地を中心に, 東西 $7 \mathrm{~km}$, 南北 $10 \mathrm{~km}$ の 調査域を設定し，そこにみられる社寺境内を調査対象と した。本研究では，樹林として孤立した社寺林を研究対 象とすることとし, 調查した社寺境内は, 神社が 59 力 所，寺院が 45 力所であった。境内の面積は最大で 1.55 ha, 最小が 0.001 ha であった。対象となった社寺林は, 市街地中心部の密集地に囲まれたものから, 宅地, 田畑 などに囲まれたすのまでみられる。

調査は，個々の社寺林において境内全域を対象とし， 樹木について植生調查を行った。樹高が胸高以上の個体 について樹種を同定し, 胸高直径を記録した。樹種につ いては, 品種, 変種を種のレベルにまとめた。胸高直径 は，胸高以上の高さの萌芽個体，枝分かれ，株立につい ても測定した。また，今後の追跡調査に備えて個体の位 置図を作製した。

\section{3. 結果および考察}

\section{1 種組成}

調查対象の社寺林を 1 つにま之めた種組成として, 各 樹種の頻度 $(\%)$, 密度 (/ha), 単位面積当りの胸高断 面積合計 $\left(\mathrm{m}^{2} / \mathrm{ha}\right.$ )を求めた（表 1$)$ 。表には頻度が 20 $\%$ 以上の樹種について樹種毎に示し，その他の樹種は まとめて示した。出現種数は合計 198 種であった。面積 としては社寺境内の敷地面積を用いた。単位面積当りの 胸高断面積合計の值は $12.94 \mathrm{~m}^{2} / \mathrm{ha}$ で, 自然林に比心 非常に低かったが，これは，社寺境内の敷地が全て樹林 で覆われているわけではなく, 建築物, 空地や墓地など が含まれていることによる。

胸高断面積合計の相対值をむとに優占構成種法 ${ }^{11}$ に よって全体の優占種数と優占種を決定した。優占種は 10 種であり, クスノキ (Cinnamomum camphora), イチョウ (Ginkgo biloba), ムクノキ (Aphananthe aspera), クロガネモチ (Ilex rotunda), エノキ (Celtis sinensis), ヒノキ(Chamaecyparis obtusa), アラカシ (Quercus glauca), スギ (Cryptomeria japonica), クロマッ (Pinus thunbergii), イブキ (Juniperus chinensis) が優占種に数えられた。これ らのうち落葉広葉樹は，密度が他と比べ低かった。これ ら優占種に数えられなかった樹種の中では，イロ八モミ ジ (Acer palmatum) とヤブッバキ Camellia japonica）は，頻度と密度が比較的高かった。

このような種組成をみると，いわゆるシイ，カシの類 の優占度が非常に低いことが特徴であると考えられる。 
表 1 調査対象社寺林全体の種組成. 頻度 (\%), 密度 (N/ha), 胸高断面積合計 $\left(\mathrm{m}^{2} / \mathrm{ha}\right)$

Table 1 Floristic composition of all studied woods in shrine or temple precincts of Okayama. Frequency $(\%)$, density $(\mathrm{N} / \mathrm{ha})$ and basal area $\left(\mathrm{m}^{2} / \mathrm{ha}\right)$ are given by species.

\begin{tabular}{|c|c|c|c|}
\hline Species & $\begin{array}{c}\text { Frequency } \\
(\%)\end{array}$ & $\begin{array}{l}\text { Density } \\
\text { (N/ha) }\end{array}$ & $\begin{array}{c}\text { Basal area } \\
\left(\mathrm{m}^{2} / \mathrm{ha}\right)\end{array}$ \\
\hline Cinnamomum camphora* & 41.5 & 29.1 & 3.38 \\
\hline Ginkgo biloba* & 53.8 & 8.0 & 1.25 \\
\hline Aphananthe aspera* & 25.5 & 6.3 & 0.96 \\
\hline Ilex rotunda* & 67.9 & 28.1 & 0.83 \\
\hline Celtis sinensis* & 32.1 & 10.9 & 0.63 \\
\hline Chamaecyparis obtusa* & 34.9 & 42.6 & 0.46 \\
\hline Quercus glauca* & 41.5 & 18.7 & 0.46 \\
\hline Cryptomeria japonica* & 44.3 & 25.5 & 0.45 \\
\hline Pinus thunbergii* & 48.1 & 30.9 & 0.44 \\
\hline Juniperus chinensis* & 43.4 & 37.1 & 0.35 \\
\hline Trachycarpus sp. & 30.2 & 10.3 & 0.18 \\
\hline Podocarpus macrophrllus & 39.6 & 19.1 & 0.13 \\
\hline Acer palmatum & 56.6 & 23.8 & 0.14 \\
\hline Prunus sp. & 45.3 & 10.9 & 0.14 \\
\hline Ternstroemia gymnanthera & 29.2 & 5.9 & 0.12 \\
\hline Camellia japonica & 57.5 & 33.3 & 0.10 \\
\hline Quercus phillyraeoides & 28.3 & 12.1 & 0.10 \\
\hline Ligustrum japonicum & 37.7 & 16.5 & 0.10 \\
\hline Viburnum odoratissimum & 22.6 & 6.1 & 0.09 \\
\hline Chamaecyparis pisifera & 20.8 & 11.9 & 0.08 \\
\hline Diospyros kaki & 27.4 & 4.6 & 0.08 \\
\hline Osmanthus fragrans & 40.6 & 6.8 & 0.05 \\
\hline Punica granatum & 28.3 & 3.5 & 0.03 \\
\hline Osmanthus heterophyllus & 20.8 & 2.2 & 0.03 \\
\hline Prunus mume & 32.1 & 7.6 & 0.03 \\
\hline Magnolia liliflora & 24.5 & 3.0 & 0.02 \\
\hline Hibiscus syriacus & 29.2 & 7.7 & 0.02 \\
\hline Lagerstroemia indica & 25.5 & 3.2 & 0.02 \\
\hline Rhododendron sp. & 25.5 & 4.4 & 0.02 \\
\hline Euonymus japonicus & 34.9 & 9.1 & 0.02 \\
\hline Fatsia japonica & 36.8 & 9.2 & 0.02 \\
\hline Camellia sasanqua & 21.7 & 7.7 & 0.01 \\
\hline Aucuba japonica & 38.7 & 6.3 & 0.01 \\
\hline Nandina domestica & 46.2 & 14.7 & 0.01 \\
\hline Deutzia crenata & 21.7 & 2.1 & 0.01 \\
\hline Others (163 species) & - & 131.2 & 2.18 \\
\hline Total & & 610.4 & 12.94 \\
\hline
\end{tabular}

*: Dominant species determined by the dominant analysis baced on relative basal area.

社寺林には，極相的な樹種がみられることが多く，優占＼cjkstart寺林では，例えば橿原神宮のように周辺の自然林を参考 しないまであ極相樹種が残存していることが多いとされとしてカシ類など郷土種を主な構成樹種とするという例

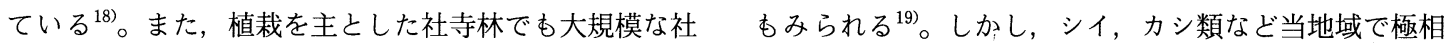


樹種と考えられる樹種の優占度は非常に低かった。ただ, クスノキは極相樹種と考えられ，これは植栽されること あ頻繁であると考えられる。シイやカシ類が少ない原因 としては, 研究対象域が市街地平地部であり, 開発の影 響を受けやすく，また，戦災を受けた社寺が多いことか ら，自然林として残存することが少なく，植栽によるこ とが多いこと, シイやカシ類が生育するのに適した立地 であるのかどうかという点, 植栽樹種選択に対する考え 方によることがあげられるが，それぞれどれほどの要因 となっているかは今のところ特定できない。今後，生態 学的な精査や樹種選択の聞込み, 資料調査が必要であり, さらに, 山麓部の社寺林や, 農村部で社寺林を調査して みることによって，これらのことを明らかにしなければ ならない。

都市域の樹林では，シュロ類（Trachycarpus sp.）, アオキ (Aucuba japonica), ヤッデ (Fatsia japonica）の繁茂が樹林の本来の構造に質的な変化をむた らすものとして問題となっている ${ }^{4,5,20)}$ 。今回調查した 社寺林についても，シュロ類，アオキ，ヤッデの頻度は いずれも $30 \%$ 以上であり，また，樹高が胸高以下の個 体についても頻繁に観察された。これらの樹種は，鳥に よって種子が散布されることによって都市域で分布を拡 大していると考えられているが, 社寺林はこれらの樹種 によって構造に変化が生じていると同時に，このような 都市域の樹林の質的な変化を生じさせる種子源になって いる可能性が考えられる。この問題は, これら特定の種 に限らない。優占種とした 10 種の中でも針葉樹を除け ば，アラカシ以外は肉質の果肉のある核果か液果である。 樹林の孤立化の進行にと屯ない重力散布型の種が減少し, 動物散布型の種が増加する傾向屯みられる ${ }^{6)}$ 。したがっ て，今後，社寺林を含め鳥による種子散布に十分注意す る必要がある。しかし，ただ単に鳥によって種子が散布 された樹種を排除するということではなく，積極的にこ れを利用し，管理することによって目的に応じた樹林を 維持することも検討すべきである。

\section{2 構成林木の直径階分布}

胸高直径の測定をもとに構成林木の直径階分布を調べ た。まず, 全樹種合計の直径階分布と, 常緑広葉樹, 落 葉広葉樹, 針葉樹に分けた直径階分布を図 1 に示した。 針葉樹は，常緑性樹種と落葉性樹種を分けていない。頻 度（個体数）は対数で示しており，ここには主幹だけの 頻度が示され，萌芽，枝分かれは除いている。

全樹種合計の直径階分布をみると, 小径木の非常に多 い型を示していた。すなわち, 直径階の増加に対して指 数関数的に個体数が減少していた。常緑広葉樹, 落葉広

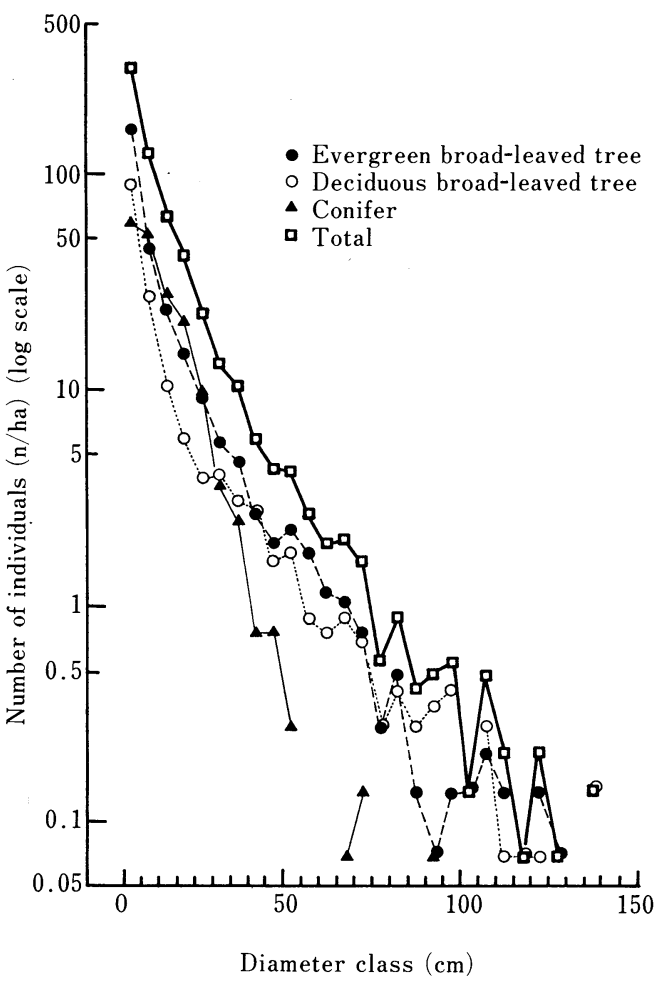

図 1 調査対象社寺林の胸高直径階分布

Fig. 1 Size-class (DBH) distribution of stems for all trees of studied woods in shrine or temple precincts of Okayama.

葉樹，針葉樹といった生活型で分けてみてもこの傾向は ほぼ同様であった。しかし，針葉樹は他の生活型と比べ て分布の幅が非常に狭く，大径木が欠けていることが明 かであった。また，直径が 0 〜 $\mathrm{cm}$ の範讲にある個体 数がやや落ち込んでいた。常緑広葉樹と落葉広葉樹は同 様な分布の型を示していたが，落葉広葉樹の方が小径木 の割合が低く，大径木の割合が高かった。

この直径階分布は研究対象とした社寺全体の分布なの で，個々の社寺林についてはまた別に論議されねばなら ない。しかし，全体としてみれば，低木種から高木種に かけて植栽が行われ，また，樹種によっては自然な更新 があることによって，小径木の多い連続的な分布が認め られたものと考えられる。

次に, 全体で優占種とした主要な樹種についてその直 径階分布をみた。まず，常緑広葉樹のクスノキ，クロガ ネモチ，アラカシについて図 1 と同様に示した（図 2）。 アラカシとクロガネモチについては，ほぼ同様な分布を 


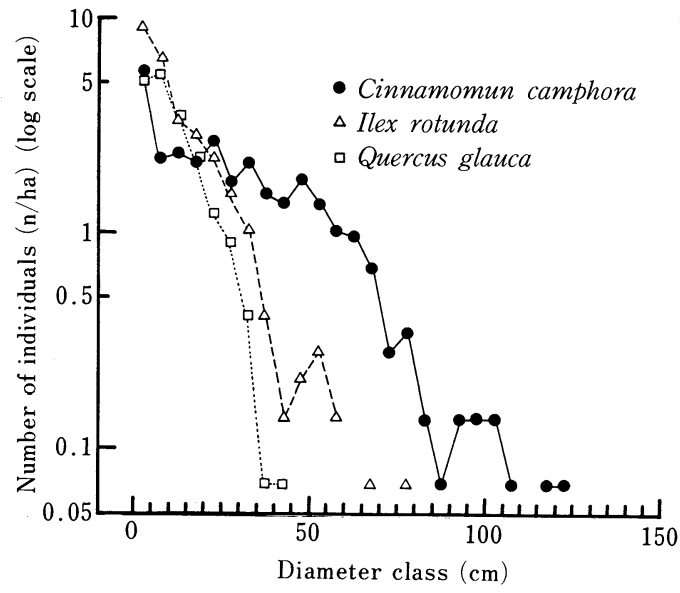

図 2 調査対象社寺林全体における主要常緑広葉樹 種の胸高直径階分布

Fig. 2 Size-class (DBH) distribution of stems for dominant evergreen broadleaved tree species.

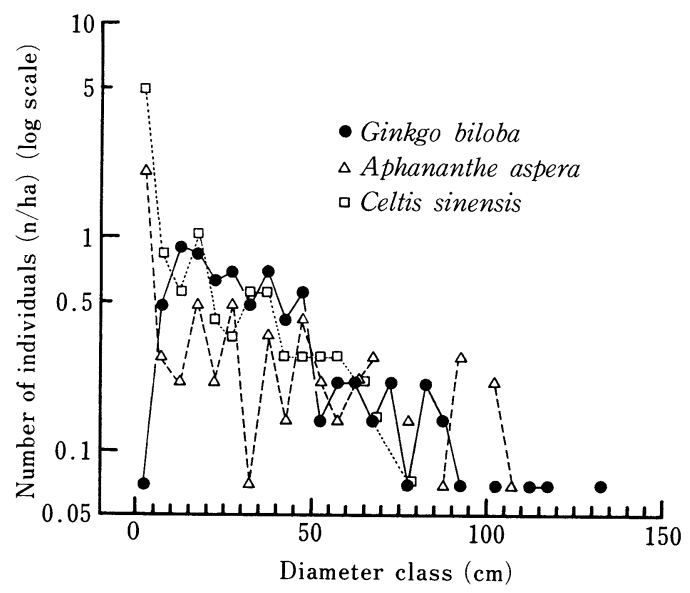

図 3 調查対象社寺林全体における主要落葉広葉樹 種の胸高直径階分布

Fig. 3 Size-class (DBH) distribution of stems for dominant deciduous broadleaved tree species.

示したが，アラカシについては $0 \sim 5 \mathrm{~cm}$ の範囲でやや 落ち込んでおり，クロガネモチの方がやや分布の幅が広 かった。クスノキはこれら 2 種とは異なった分布の型を 示し，大径木の個体が非常に多かった。クスノキは生長 が非常に速いため短期間で大径木までに生長するが，そ れだけではなく他の樹種に比べ古くから植栽されていた
と考えられる。

落葉広葉樹では，イチョウ，ムクノキ，エノキについ て示した（図 3）。エノキ, ムクノキは，直径階毎の変 動は著しいが，小径木の個体が多い分布の型を示してい た。これらとは対照的にイチョウは大径木が非常に多く, 小径木が極端に少なかった。イチョウは社寺に植栽され ることが頻繁な樹種であるが，植栽時の直径を反映して いるのかあしれない。逆に，ムクノキ，エノキは他の樹 種と比べ植栽されることが少ない樹種であると思われる。 これらの樹種に関して小さな個体が多いことは，自然な 更新か頻繁に起こっていることが考えられる。ムクノキ, エノキは比較的先駆種的な樹種であると考えられ，社寺 林の中でも階層構造が発達し極相林的な構造を有する保 護林においては下層木あるいは小径木が欠ける傾向があ り，林冠欠損部か林縁でしか更新がみられない16)。今回 調査した社寺林は，保護林的な扱いを受けているものが 少なく，人の立ち入りなどの影響が大きなものが多かっ た。しかも樹林は境内の周縁部に分布することが多く， 樹林の形としても幅が狭いものが多かった。このような 樹林の形態のため, ムクノキ，エノキの小径木の個体む 十分に維持されるあのと考えられる。

針葉樹に関しては，ヒノキ, スギ, クロマッ, イブキ

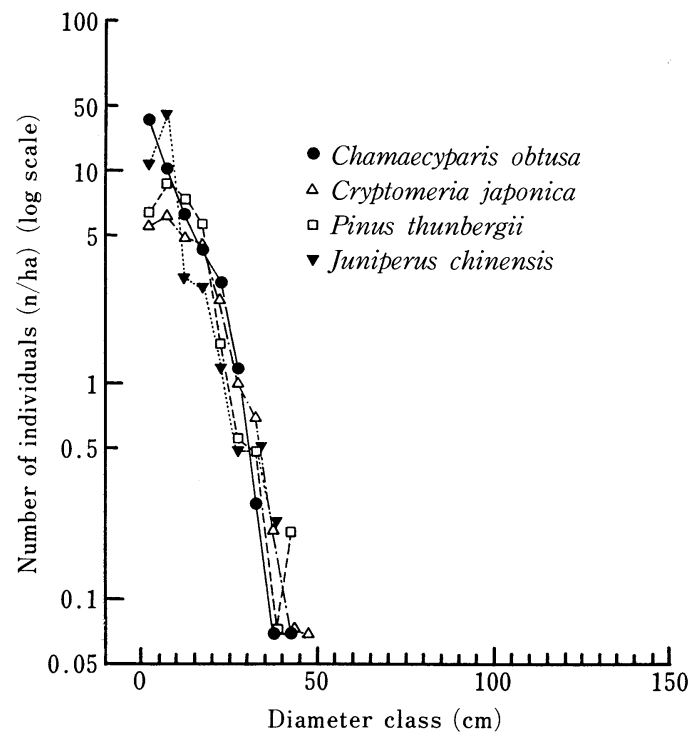

図 4 調査対象社寺林全体における主要針葉樹種の 胸高直径階分布

Fig. 4 Size-class (DBH) distribution of stems for dominant coniferous tree species. 
について示した（図 4)。これら4種の針葉樹 は直径階分布が非常に似通っていた。ただ，七 ノキについては 0 $5 \mathrm{~cm}$ の小径木が多かった が，そのほかの樹種は $5 \sim 10 \mathrm{~cm}$ の範囲に分布 のモードを持つ 1 山型の分布を示した。広葉樹 に比べ分布の幅が非常に狭いことは，全樹種を 合計してみたときと同様である。これら針葉樹 の生長について調べていないので確定的には言 えないが，広葉樹に比べ針葉樹は，比較的近年 に一斉的に植栽されたことが考えられる。

以上主要な樹種についてその直径階分布をみ てきたが, 小径木の頻度が高くしかも大径木ま で連続的な分布を示すムクノキ，エノキ，これ と同様であるが，特に大径木の頻度の割合が高いクス， キ，大径木の頻度が高く小径木の頻度の低いイチヨウ， 小径木の頻度は高いが直径の幅が狭いクロガネモチ，了 ラカシ，針葉樹という4つのタイプが考えられた。この うち，ムクノキ，エノキ，クスノキ，クロガネモチに関 しては, 全体としてみ机ば安定した構造を示していると 考えられる。これらの種では鳥によって種子が散布され たことによって新たに更新したものが含まれていると考 えられ，今後これを定量化することが必要である。

\section{3 多様性}

3.1 において種組成をみたが，樹種毎の胸高断面積合 計からみると特に際だった優占種はみられず，優占構成 種法によっても優占種は 10 種を数えた。したがって, 今回対象とした社寺林は全体的にみれば構成樹種は多様 であり，様々な種組成の社寺林が存在すると考えられる。 このような多様性の問題に関して，ここでは，社寺境 内の面積と種数, 多様度の関係について検討した。まず, 社寺境内面積と種数との関係では, 両変数を対数に変換 した場合に正の相関がみられた（図 5)。すなわち，面 積の増加に伴う種数の増加がみられた。この関係は, MAC ARTHUR and WILSON (1967) ${ }^{10)}$ の種数一面積関 係を示す関数に当てはめることができる。すなわち，

$$
\mathrm{S}=\mathrm{kA}^{\mathrm{z}}
$$

ここで， $\mathrm{S}$ は種数， $\mathrm{A}$ は面積， $\mathrm{k}$ 抢よび $\mathrm{z}$ はそれぞれ 定数, 係数である。

この関数は, 生物地理学的な観点から島の面積と種数 の関係を考慮したものであり，この場合当然のことなが ら本土との距離, 島間の距離, 島内の habitat の多様 性など様々な問題が包含されている。理論的には種数一 優占度の関係をむとに島に関するだけでなく，ある一定 の地域内においても成り立つことが証明されている ${ }^{14)}$ 。 近年では, 残存林についてあ同様な視点で取り組まれて

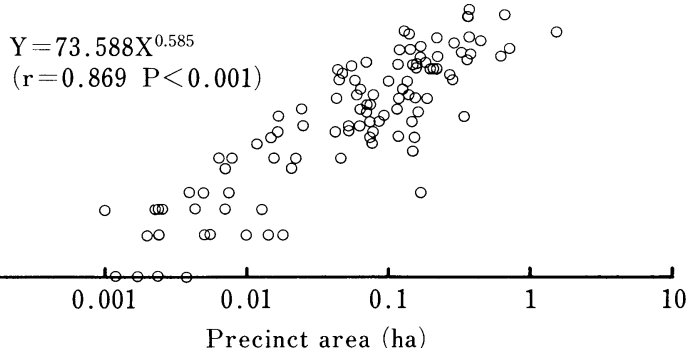

図 5 社寺境内面積と出現種数との関係

Fig. 5 Relationship between the number of species and area of shrine or temple precinct.

おり, 同様な結果む得られている ${ }^{12,13)}$ 。しかし, 自然林 としての残存林では成り立たないことも多い。例えば, 面積によって，林縁部，林内部の出現の割合が変化する ため，林緑種と林内極相種の出現の割合の変化によって 必ずしも上記の関係が成り立たない9。FORMAN and GODRON (1986) ${ }^{3)}$ はそれまでの研究成果をまとめ, 種 数のみならず種の多様性に関し, 残存林に当てはめると すれば, 面積, habitat の多様性, 生態学的擋乱, 残存 林の林齢, 周辺景観の異質性, 隔難度, 残存林の形態を 主要な説明変数とすべきであると述べている。今回の結 果は, 植栽を主としていると考えられる社寺林について 得られた結果であり，このような人工的な樹林において あ種数一面積関係に上記のような関係が得られたことは 興味深い。逆に，植栽を主とした樹林であることによっ てこのような関係が得られたとも考えられる。

また，様々な地域，植生で得られている植生に関する

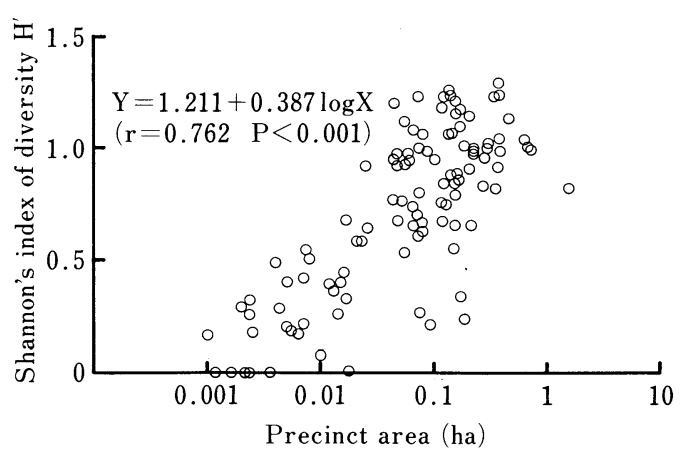

図 6 社寺境内面積之胸高断面積による優占度をも とにした Shannon 関数との関係

Fig. 6 Relationship between Shannon's index of diversity and area of shrine or temple precinct. 
$Z$ の值は, 0.5 を下迴ることが多く7,14,17), 今回の調査 で得られた Z の值， 0.585 は非常に高い值の部類に属 している。他の結果と比べ調査方法も異なり, 対象面積 が小面積に限られ, 非常に小さな面積を含んだためとも 考えられ, 単純に比較することは問題を残すが, 他の孤 立林での関係と相対的に比べると, 小面積の社寺林にお いては種数が非常に少なく, 大面積の社寺林になるほど より多くの種を維持することができると考えられる。独 特の植栽と維持管理による社寺林の場合の特質であるか あしれない。また，Zの值が高いことは，孤立林として の隔離度の高さを示しているとされ ${ }^{10,13)}$, 今回の社寺林 のように市街地の密集地, 宅地, 田畑の中に点在してい ることも Z の值が高い要因となっている可能性も考え られる。

次に, 多様度を示す指数として Shannon 関数を求 め面積との関係を検討した（図6)。Shannon 関係は以 下の式で求めた。すなわち,

$$
\mathrm{H}^{\prime}=-\sum_{\mathrm{i}} \mathrm{p}_{\mathrm{i}} \log \mathrm{p}_{\mathrm{i}}
$$

$\mathrm{p}_{\mathrm{i}}$ としては, 種毎の胸高断面積合計の相対值を用いた。 図は, 面積だけを対数で示している。この場合も正の相 関がみられた。また， $\mathrm{H}^{\prime}$ の值が $\mathrm{O}$ のあのを除き $\mathrm{H}^{\prime}$ を対数変換した場合にも正の相関がみられ（ $\mathrm{r}=0.632$ $\mathrm{p}<0.001)$, 以下の式が導かれた。すなわち,

$$
\mathrm{H}^{\prime}=1.473 \mathrm{~A}^{0.305}
$$

Shannon 関数は, 優占度の中間的な種の貢献度が高 く優占度の上位種, 下位種の貢献度が低くなるが, 種の 均等性を反映する指数と考えられる ${ }^{8)}$ 。したがって, 種 の均等性を考慮してあ面積の増加に伴って多様度が増加 する傾向があると考えられる。

以上, 調查対象とした社寺林についてその多様性の問 題を社寺境内面積との関係で検討したが, 面積の増加に 伴う種数, 多様度の増加を認めることができた。社寺独 特の樹種選択と維持管理, 面積が増大するにしたがって 社寺境内の微細な土地利用が多様となることなど様々な 要因が考えられる。今後この多椂性の問題に関しては, 面積だけでなく, 社寺林内部の土地利用の多様性, 植栽 や維持管理の形態, 歴史, 周辺の土地利用, 社寺境内の 形態社寺間の距離などと対応させ, さらに検討すること が必要であり, 今後検討する予定である。

\section{4. 今後の展開と課題}

今回の報告は, 対象となった社寺林を 1 つにまとめ構 造をみることによって全体的な特徴を検討した。神社と 寺院の相違, 管理形態, 歴史、社寺境内内部之周辺の土
地利用, 前述した面積や種子散布の問題などによって社 寺林の構造は変化するものと考えられる。これらのこと を明らかにするためには, まず対象となった社寺林を分 類することから始めなければならないであろう。この点 に関しては, 次稿において検討したい。このことによっ て, 環境林造成の基礎的な参考として社寺林の評価が明 らかになるものと思われる。

本研究は岡山市を対象としており, 今回は特に平地部 市街地とその近郊を対象に絞っている。今後, 山麓部や 農村部の社寺林と比較検討することが必要であり, さら に地域の異なった社寺林と比較することにより, 地域特 性を抽出すること屯検討すべきであろう。

\section{参考文 献}

1) Burgess, R.L. and Sharpe, D.M. (eds.): Forest Island Dynamics in Man-Dominated Landscapes. 310 pp. Springer-Verlag. New York. 1981

2）千葉喬三 : 環境林造成の課題とこれからの技術. 緑化工 学会誌, 15 (1), 17-20, 1989

3) Forman R, T.T. and Godron, M. : Landscape Ecology. 619 pp. John Wiley and Sons. New York, 1986

4）萩原信介: 都市林におけるシュロとトウジュロの異常繁 殖. I . 種子の散布と定着, 自然教育園報告, 7, 19-31, 1977

5）—: 都市林におけるシュロとトウジュロの異常繁 殖. II . 自然教育園における分布の拡大と分布型につい て，自然教育園報告，9，1-11，1979

6) 浜畑悦治 : 都市化に伴う武蔵野平地部二次林の草本層種 組成の変化一都市近郊の森林植生の保全に関する研究 I 一. 日生態会誌, 30, 347-358, 1980

7) Hooper, M.D. : The size and surrounding of nature reserves. Symp. Br. Ecal. Soc., 555-561. 1970

8）伊藤秀三編 : 進群落の組成と構造. 植物生態学講座 2 , $322 \mathrm{pp}$. 朝倉書店, 東京. 1977

9) Levenson, J.B.: Woodlots as Biogeographic Islands in Southeastern Wisconsin. 13-39. In Burgess, R.L. and Sharpe, D.M. (eds.), Forest Island Dynamics in Man-dominated Landscapes. Springer-Verlag. New York. 1981

10) Mac Arthur, R.H., and Wilson, E.O.: The theory of island biogeography. $203 \mathrm{pp}$. Princeton University Press, Princeton, New Jersey. 1967

11）大沢雅彦・鈴木三男・渡辺隆一 - 入倉清次 - 阿部葉子 : 富士山における垂直分布帯の形成過程. 富士山総合学術 調查報告書, 371-421，富士急行 (株), 東京, 1971

12) Peterken, G.F.: A method of assessing woodland flora for conservation using indicator species. Biol. Conserv.,6, 239-245. 1974

13) Peterken, G.F.: WOODLAND CONSERVAtion and MANAGEMENT. 328 pp. Chapman and Hall, London, 1981.

14) Preston, F.W. : The canonical distribution of commonness and rarity : Part I. Ecology, 43, 185-215, 1962

15）緑地研究会: 社寺林の研究 1 12. 森林, 1 12, 土井林 
学振興会, 1974 1984

16）坂本圭児・小林達明・池内善一：京都，下鴨神社の社寺 林における林分構造について. 造園雑誌，49（5)，275280, 1985

17) Soanlan, M.J.: Biogeography of Forest Plants in Prairie-Forest Ecotone in Western Minnesota. 97-124, In Bargess, R.L. and Sharpe, D.M. (eds.), Forest Island Dynamics in Man-dominated Landscapes.
Springer-Verlag. New York. 1981

18）四手井綱英 : 宮ノ森の維持，保存の意義. 社寺林の研究， 10, 森林, 10, 13-19. 土井林学振興会, 1979

19）管沼孝之・堀部真理 : 橿原神宮境内林の林木の動態. 社 寺林の研究, 5, 森林, 5, 125-160, 土井林学振興会, 1976

20）山本進一: 孤立林のダイナミクス. 生物科学, 39 (3), 121-127, 1987

\section{Summary}

Sakamoto Keiji, Ishinara Shinji and Chiba Kyozo: Study on the woods in shrine or temple precincts of Okayama, Japan (I). - Total structure of the woods in shrine or temple precincts, in urban and suburban areas-.

For the purpose of analyzing the system for the maintenance of woods in shrine or temple precincts, the woods structure was researched in Okayama City. In this paper, total structure of the woods was studied. Cinnamomum camphora, Ginkgo biloba, Aphananthe aspera, Ilex rotunda,Celtis sinensis, Chamaecyparis obtusa, Quercus glauca, Cryptomeria japonica, Pinus thunbergii and Juniperus chinensis were thought to be dominant. Low dominance of evergreen oak and Castanopsis trees characterized total structure of studied woods. Diameter class distributions of dominant species were classified into four types as follows. 1; frequency of small size trees was high and frequency decreased gradually to large size trees (Aphananthe aspera and Celtis sinensis). 2; frequency of small size trees was high and frequency decreased gradually to large size trees but the rate of large size trees was high (Cinnamomum camphora). 3 ; frequency of small size trees was low and those of middle and large size trees were high (Ginkgo biloba). 4 ; frequency of small size trees was high but large size trees were absent (Ilex rotunda, Quercus glauca and coniferous tree species). As for the total of all species, frequency of small size was high and frequency decreased exponentially. In order to study the diversity, relationships between the number of species or Shannon's index and area were examined. In both relationships, correlations were indicated and it was proved that the diversity increaed with the increase of area. In the relationship between the number of species and area, the function $\mathrm{S}=\mathrm{kA}^{\mathrm{z}}$ (S : number of species, $\mathrm{A}:$ area, $\mathrm{k}$ and $\mathrm{z}$ : constants) was fitted to the points. The value of $\mathrm{z}$ was 0.585 and was thought to be very high and the feature of the studied woods. 